\title{
MENINGKATKAN KUALITAS PENDIDIKAN, KESEHATAN DAN TEKNOLOGI MELALUI PROGRAM KKN TEMATIK DI DESA BOJONG RANGKAS
}

\author{
Maemunah Sa'diyah ${ }^{1}$, Ucu Shita, Firda Anggun S R ${ }^{2}$. \\ maemunah@fai.uika-bogor.ac.id \\ Dosen Fakultas Agama Islam ${ }^{1}$, Mahasiswa KKN Kelompok 10 Tahun $2018^{2}$
}

\begin{abstract}
ABSTRAK
Peningkatan kualitas pendidikan, kesehatan dan teknologi pada hakikatnya dapat dibedakan, tetapi tidak dapat dipisahkan. Ketiga istilah tersebut merupakan satu kesatuan dalam pembelajaran. Pendidikan merupakan pilar dalam memainkan peran kunci dalam membentuk kemampuan sebuah negara berkembang. Upaya meningkatkan kualitas pendidikan, kesehatan dan teknologi di tujukan pada masyarakat, agar mau dan mampu dalam memperbaiki kualitas kehidupan dengan ilmu pengetahuan yang di dapatkan. Peningkatan kualitas pendidikan, kesehatan dan teknologi disini juga mempunyai beberapa tujuan yaitu: (1) Meningkatkan pengetahuan pentingnya pendidikan (2) Menerapkan pola hidup sehat (3) Meningkatkan kesadaran pemanfaatan teknologi. Metode pendekatan yang digunakan dalam kegiatan ini adalah: (1) Pendekatan religius (2) Pendekatan kekerabatan (3) Pendekatan berdasarkan karakter masyarakat. Setelah kegiatan ini masyarakat Desa Bojong Rangkas khususnya warga kampung pangkalan dua diharapkan lebih mengetahui bagaimana pentingnya pendidikan, kesehatan dan teknologi.
\end{abstract}

Kata Kunci : Pendiidkan, Kesehatan, Teknologi

\section{PENDAHULUAN}

Kuliah Kerja Nyata merupakan program pendidikan dengan memberikan pengajaran kepada mahasiswa untuk beradaptasi dengan masyarakat. Ada beberapa tahap diantaranya persiapan, pembekalan, observasi sampai pada tahap evaluasi. Persiapan merupakan kegiatan sebelum KKN dilaksanakan, persiapan dilakukan agar kegiatan dapat terlaksana dengan terstruktur dan terarah. Persiapan dilakukan oleh pihak LPPM selaku koordinator dan mahasiswa sebagai peserta KKN. Tujuan dari KKN sendiri adalah mahasiswa diharapkan dapat memberikan bantuan pemikiran, tenaga, dan ilmu pengetahuan dalam merencanakan dan melaksanakan program memajukan desa.

Ketika mahasiswa berada di lokasi KKN, para mahasiswa melakukan kegiatan observasi. Kegiatan ini dilakukan untuk mengamati secara langsung terhadap permasalahan apa yang sedang dihadapi masyarakat dan mahasiswa diharapkan dapat memecahkan permasalahan tersebut. Inilah yang disebut Kuliah Kerja Nyata Tematik.

Kelembagaan sebagai unsur penting lainnya yang menunjang pembangunan ekonomi pedesaan telah terbentuk dengan baik. Desa Bojong Rangkas memiliki lembaga ekonomi penting. Namun kelembagaan yang mengelola sampah 
belum ada atau belum tersentuh sehingga dalam pengelolaan sampah yang sangat berperan adalah individu-individu masyarakat tersebut atau tergantung pada pemahaman dan kesadaran dari masyarakat, sebenarnya dari hasil survey lapangan dan initerview dengan beberapa tokoh masyarakat di desa Bojong Rangkas sudah ada, sebagian masyarakat yang mulai melakukan pemilihan sampah-sampah yang memiliki nilai ekonomis, namun itu hanya sebagian kecil saja berdampak pada permasalahan sampah secara keseluruhan. Demikian potensi-potensi tersebut belum maksimal dalam meningkatkan kepedulian masyarakat terhadap perlunya penanganan sampah, menurut analisis kami terdapat beberapa faktor yang mengakibatkan hal tersebut terjadi, diantaranya adalah :

1. Tingkat adopsinya terhadap inovasi serta proses pengambilan keputusan terutama yang berkaitan dengan kegiatan sampah. Selain itu, belum berkembangnya teknologi pengolah sampah di kalangan masyarakat menyebabkan sampah belum mendapatkan nilai tambah.

2. Kurangnya dorongan atau sosialisasi dari pihak pemerintahan atau pihak-pihak yang terkait dengan masalah sampah.

\section{Letak Geografis}

Desa Bojong Rangkas merupakan salah satu desa di wilayah Kecamatan Ciampea Kabupaten Bogor dengan Luas Wilayah 104,000 Ha. Letak koordinat yaitu 106.69865 BT / -6.579147 LS, dengan 2 iklim yang terjadi yaitu musim penghujan dan musim panas. Yang terbagi dalam 9 Rukun Warga (RW), 41 Rukun Tetangga (RT). Batas Wilayah Desa Bojong Rangkas adalah sebagai berikut :

\begin{tabular}{|c|c|c|}
\hline No & Arah & Berbatasan \\
\hline 1 & Utara & Desa Benteng \\
\hline 2 & Timur & Desa Tegal Waru \\
\hline 3 & Selatan & Desa Cicadas \\
\hline 4 & Barat & Desa Cibadak \\
\hline
\end{tabular}

\section{Kondisi Masyarakat}

Kondisi masyarakat berhubungan dengan suatu wilayah yang terdapat penduduk, tetapi keadaan penduduk tiap wilayah berbeda-beda. Hal ini disebabkan oleh berbeda kepadatan, sosial ekonomi, mata pencaharian, budaya dan karakternya. Berikut kondisi masyarakat Desa Bojong Rangkas.

\section{Jumlah penduduk}

Jumlah Penduduk Desa Bojong Rangkas tercatat sebanyak 13.387 jiwa yang terdiri dari 7009 laki-laki, 6378 perempuan, dengan jumlah Kepala Keluarga (KK) 3431, dari jumlah keluarga yang ada di Desa Bojong Rangkas.

\section{METODE PELAKSANAAN}

\section{Metodologi Penyelenggaraan KKN}

Metode yang dimaksud disini yaitu metode pelaksanaan $\mathrm{KKN}$ yang tidak lain merupakan tindakan dari penelitian sebagai langkah awal melaksanakan KKN karena sebelum terjun kelapangan tentu saja perlu dilakukan beberapa penelitian untuk perumusan masalah dan penemuan solusi. Adapun methode-methode yang digunakan dalam pelaksanaan KKN Tematik Terintegrasi tersebut diantaranya yaitu metode etnografis dan studi kasus. 
a. Metode Etnografis

Metode etnografis yaitu metode yang digunakan untuk menginterpretasi dan mengukur budaya, kelompok sosial dan suatu sitem dalam masyarakat baik dari segi cara berfikir, adat, bahasa, kepercayaan atau pola dan tingkah laku hidup suatu masyarakat. Metode ini biasanya digunakan dan dilaksanakan dalam waktu yang cukup lama karena butuh proses dan fakta yang akurat bukan hanya perkiraan yang bisa dideskripsikan dalam kurun waktu yang singkat karena itulah butuh berbaur dan berada langsung dengan masyarakat.

Disebut menggunakan metode ini karena setiap hasil dari penelitian selalu diuraikan dalam bentuk laporan yang bersifat deskriftif baik dari budaya, cara hidup dan prilaku masyarakat yang berada dilokasi sasaran pelaksaan KKN Tematik Terintegrasi ini, sehingga dengan mudah dapat ditarik kesimpulan dan gambaran mengenai pola hidup masyarakat tersebut.

\section{b. Studi Kasus}

Studi kasus merupakan salah satu metodologi penelitian yang bertujuan untuk mempelajari suatu peristiwa,keadaan atau perkembangan suatu fenomena terkait latar belakang keadaan sekarang dan suatu interaksi sosial baik individu, kelompok, lembaga, atau masyarakat.

Studi kasus memerlukan keterampilan yang mantap karena harus berada dalam situasi senatural mungkin agar memperoleh data dan informasi yang akurat tanpa ada unsur manipulasi.Oleh karena itu perlu tahapan yang terprogram dan persiapan yang matang ketika hendak melaksanakannya.
Studi kasus melibatkan investigasi kasus yang kemudian didefinisikan sebagai objek studi yang bersipat sederhana atau dibatasi, setelah kasus didefinisikan dengan jelas maka peneliti menyelidiki kasus atau objek tersebut secara mendalam dengn mengguakan beberapa metode pengumpulan data seperti wawancara, observasi lapangan dan dokumentasi.

1. Wawancara

Wawancara adalah percakapan dengan maksud tertentu. Percakapan itu dilakukan oleh dua pihak, yaitu pewawancara (interviewer) yang mengajukan pertanyaan dan yang diwawancarai (interviewee) yang memberikan jawaban atas pertanyaan itu.

Teknik wawancara ini dilakukan dengan mengajukan beberapa pertanyaan kebeberapa narasumber di beberapa lokasi yang mana obyek tersebut sedang di teliti oleh peserta KKN. Adapun narasumber yang dijadikan sumber informasi diantaranya yaitu bapak kepala desa, sekretaris dan staf-staf desa, struktur pemerintahan warga dari mulai RW, RT, kader posyandu, tokoh masyarakat, tokoh agama setempat berikut warga masyarakat sendiri.wawancara ini bertujuan untuk memperoleh data yang tidak didapatkan melalui observasi dan angket.

2. Metode observasi

Observasi sebagai teknik pengumpulan data mempunyai ciri yang spesifik bila dibandingkan dengan teknik lain, yaitu wawancara dan kuesioner. Kalau wawancara dan kuesioner selalu berkomunikasi dengan orang, maka observasi tidak 
terbatas pada orang, tetapi juga obyek-obyek alam yang lain.

Dan dengan begitu, Penelitian ini akan menggunakan metode observasi untuk mengetahui secara langsung apa yang terdapat di lapangan tentang bagaimana sebab tuntutan nafkah istri tehadap suami yang dapat menimbulkan disharmonisasi keluarga.

3. Survey Lapangan

Survey merupakan salah satu metode yang digunakan untuk melihat langsung lokasi sasaran atau kegiatan yang dilaksanakan dilokasi sasaran sehingga mendapat informasi yang jelas, tepat dan benar serta nyata. Survey dilaksanakan untuk memberikan hasil yang pasti tentang objek yang dituju sehingga tidak ada keabstrakan dari informasi apapun.

Sasaran lokasi pelaksanaan KKN Tematik Terintegrasi untuk kelompok kami yaitu kelompok 10 diarahkan di Desa Bojong Rangkas Kecamatan Ciampea yang awalnya masih bersifat abstrak mengenai lokasi sasaran yang tepat, oleh karena itu sebelum tanggal pelaksanaan KKN peserta KKN Tematik Terintegrasi dan DPL mengadakan survey terlebih dahulu ke pihak desa dan mengadakan wawancara singkat terkait lokasi sasaran sehingga diputuskan oleh pihak kades beserta peserta KKN Tematik Terintegrasi untuk fokus di RW 05 RT 05.

4. Metode dokumentasi

Metode dokumentasi adalah mencari data mengenai hal-hal atau variabel yang berupa catatan, transkip, buku, surat kabar, majalah, prasasti, notulen rapat, lengger, agenda, dan sebagainya.
Partisipasi Masyarakat dalam

\section{Pelaksanaan Program}

Partisipasi masyarakat yang dapat dilakukan dalam kegiatan ini adalah sebagai berikut:

a. Mempersiapkan masyarakat untuk mengikuti kegiatan program kerja yang dilaksanakan.

b. Mempersiapkan tempat untuk melaksanakan program kerja.

c. Ikut membantu menyiapkan konsumsi pada pelaksanaan program kerja.

\section{Langkah Evaluasi}

Evaluasi yang akan dilakukan terdiri dari:

a. Evaluasi proses, yang terkait dengan perencanaan, pelaksanaan dan monitoring kegiatan. Evaluasi proses akan dilakukan setiap pekan bersama dengan anggota KKN.

b. Evaluasi hasil, yang akan dilaksanakan setelah kegiatan dilaksanakan. Evaluasi dampak setelah pelaksanaan pembinaan.

c. Evaluasi dampak diarahkan untuk melihat efektivitas program kerja yang telah terlaksana. 


\section{REALISASI PROGRAM}

Realiasasi Program Mahasiswa KKN dilaksanakan selama kurang lebih 30 hari terhitung sejak tanggal 7 Agustus 2018 sampai dengan 5 September 2018. Berikut ini adalah laporan berbagai kegiatan yang telah dilaksanakan oleh mahasiswa KKN di Desa Bojong Rangkas, Kecamatan Ciampea, Kabupaten Bogor. Programprogram kerja yang dilaksanakan tersebut yaitu :

\section{Program Kerja Fisik}
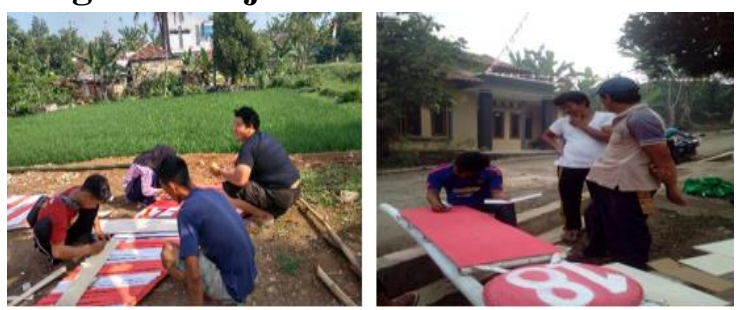

\section{Pembuatan gapura}

Kegiatan pembuatan gapura dilakukan untuk kegitatan HUT RI di RT 05 dan RT 06 Desan Bojong rangkas.

\section{Perbaikan fasilitas wc masjid RT 05}

Kegiatan ini dilakukan dalam rangka untuk mempermudah pemakaian fasilitas warga.

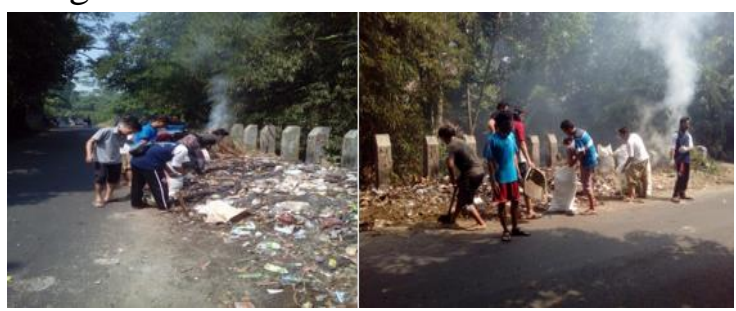

\section{Pembersihan Sampah di Jalan Utama}

Kegiatan ini bertujuan untuk membersihkantumpukan sampah yang mulai menggunung di sepanjang jalan utama desa bojong rangkas RW 05 .

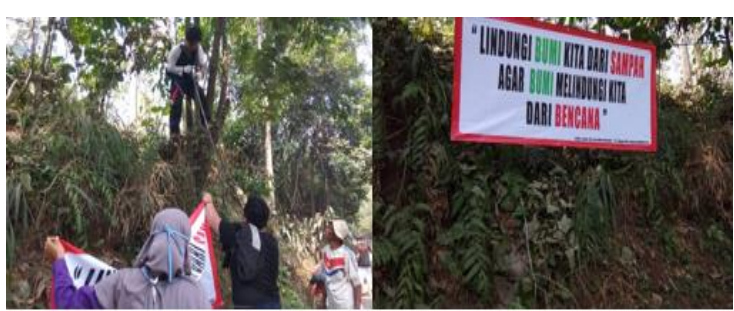

4.Pembuatan dan pemasangan pamflet peringatan

Kegiatan ini bertujuan untuk mengingatkan kepada masyarakat untuk selalu berprilaku positif.

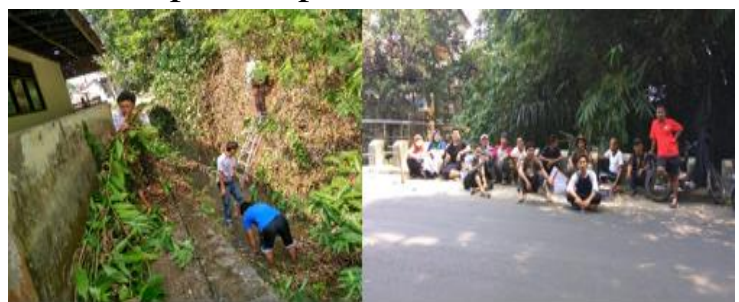

\section{Kerja Bakti}

Merupakan program kerja yang bertujuan untuk membersihkan lingkungan Desa Bojong Rangkas, agar lingkungan bebas dari berbagai macam penyakit.

\section{Program Kerja Non-Fisik}

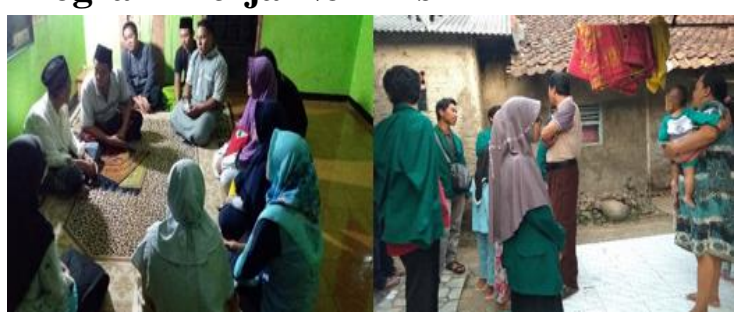

\section{Sosialisasi Program KKN}

Sosialisasi Program KKN bertujuan untuk memberitahukan kepada seluruh masyarakat Desa Bojong Rangkas terkait program kerja mahasiswa KKN. Sehingga menghindari kesalahpahaman antara mahasiswa KKN dengan masyarakat. 


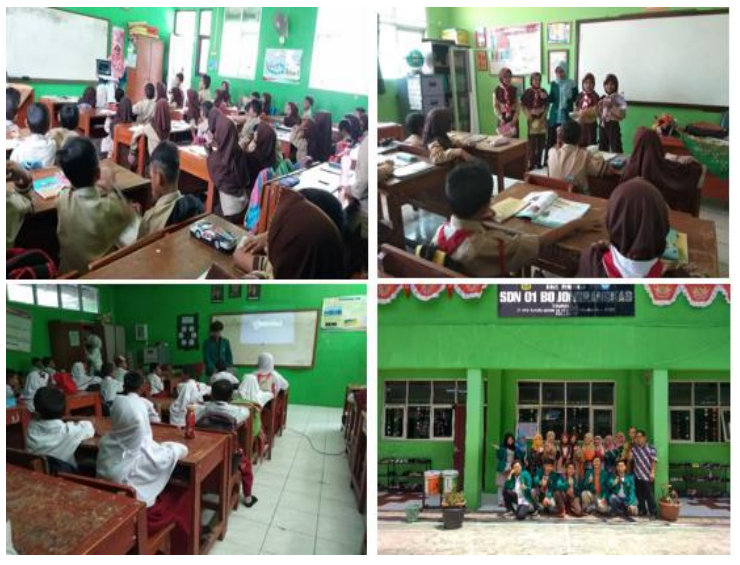

2.Mengajar di SDN 01 Bojong Rangkas

Kami selaku mahasiwa Fakultas Agama Islam khususnya di bidang pendidikan membantu kegiatan belajarmengajar yang ada di SDN 01 Bojong Rangkas, karna disana juga kurangnya staff guru di mata pelajaran Pendidikan Agama Islam. Jadi kami membantu proses pembelajaran selama kegiatan $\mathrm{KKN}$ berlangsung.
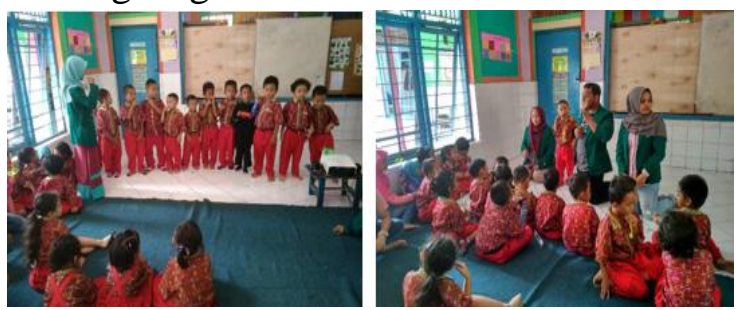

\section{Penyuluhan Kesehatan}

Penyuluhan Kesehatan berupa materi Pola Hidup Sehat (PHBS) bertujuan untuk mengajak anak kecil dan remaja di Desa Situ Udik untuk hidup sehat. Mengingat jumlah anak kecil dan remaja yang sangat banyak.

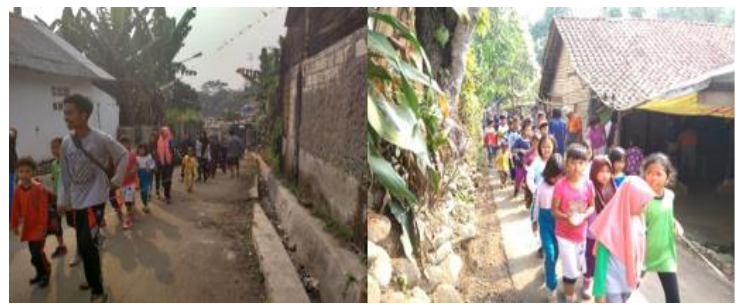

\section{Jalan Sehat}

Kegiatan jalan sehat bertujuan untuk membangkitkan semangat olahraga bersama keluarga dengan berlandaskan kekeluargaan bersama mahasiswa dan warga RT 05 RT 06 RW 05 Desa Bojong Rangkas.

\section{Cek kesehatan gratis}

Kegiatan cek kesehatan gratis ini berupa cek tekanan darah atau tensi beserta konsultasi masalah kesehatan, Tujuan dari Cek Kesehatan Gratis adalah mempermudah Masyarakat Desa Bojong Rangkas dalam rangka pengecekan kesehatan dan peningkatan mutu kesehatan Masyarakat Bojong Rangkas.

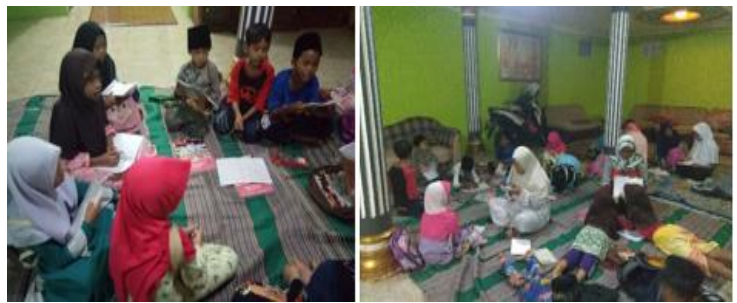

\section{Bimbingan Belajar}

Merupakan kegiatan belajar
mengajar yang bertujuan untuk memudahkan para siswa yang kesulitan belajar dan mengerjakan tugas sekolah, dengan cara yang tidak jenuh, bermain tetapi sambil belajar, agar para siswa menikmati belajarnya.
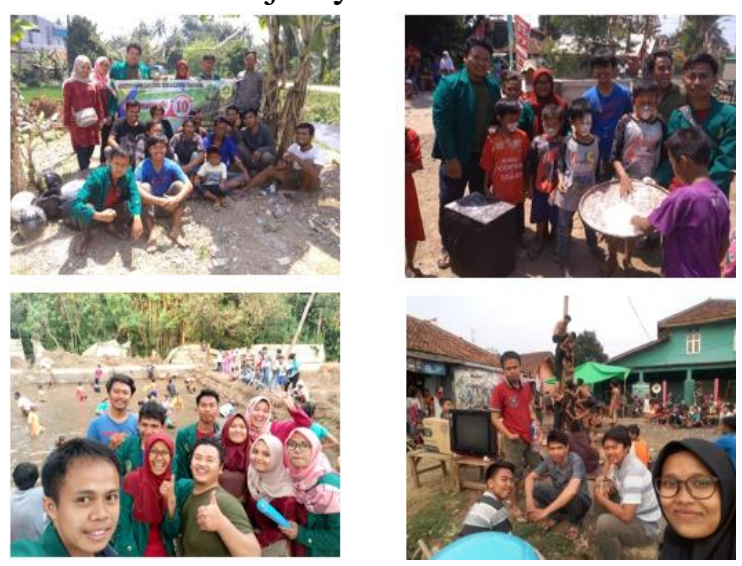

\section{Perayaan HUT RI 17 Agustus}

Merupakan kegiatan nasional yang diadakan pada tanggal 17 Agustus 1945, dengan tujuan mengenang para pahlawan yang membela tanah air, sehingga 17 Agustus diperingati sebagai Hari Kemerdekaan Indonesia. Dengan cara, 
Upacara Bendera Merah Putih, senam dan perlombaan anak-anak.

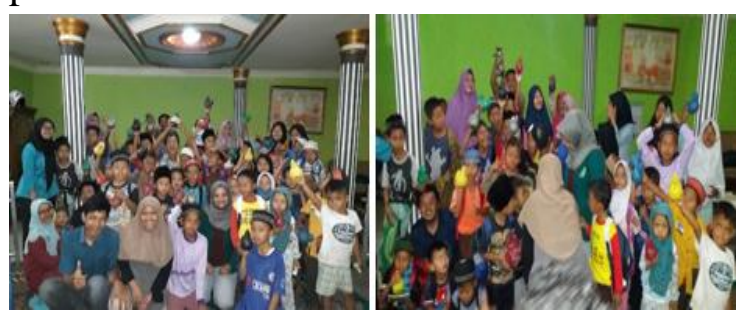

8.Sosialisasi Menabung

Kegiatan ini bertujuan untuk membiasakan menabung untuk anak-anak dan remaja di daerah Desa Bojong Rangkas. Karena menabung itu amat penting sekali untuk masa depan yang akan datang.

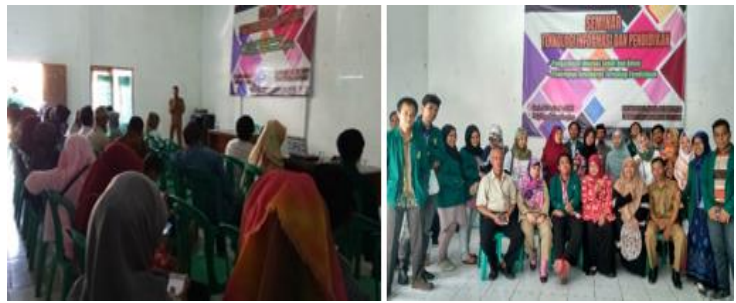

\section{Seminar Pendidikan}

Tujuan dari program ini adalah meningkatkan mutu para orang tua dan pemuda, agar terus menggali potensi ilmu tanpa ada batasan waktu atau usia.

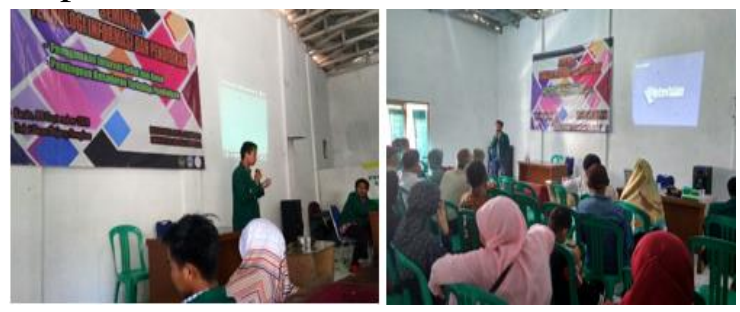

\section{Seminar teknologi}

Tujuan kegiatan ini adalah sebagai warning agar menggunakan teknologi internet harus dengan pengawasan karna banyak dampak buruk yang akan terjadi apabila penggunaan internet tidak bijak.
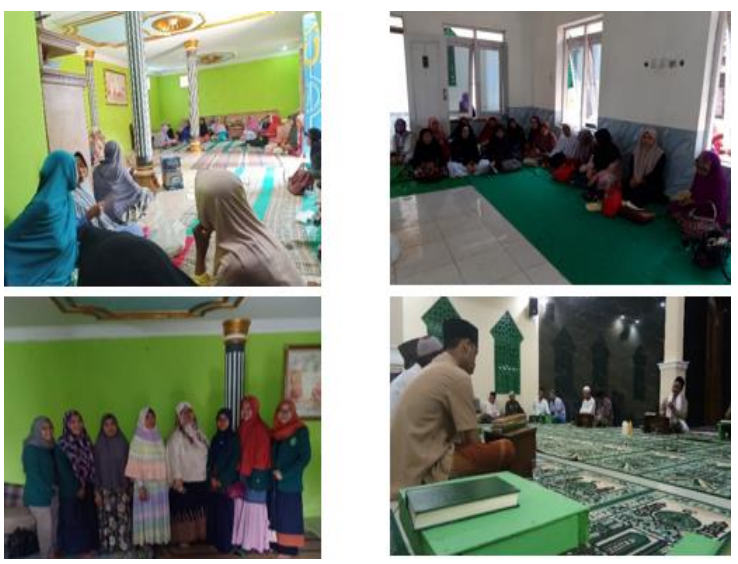

\section{Pengajian bersama}

Tujuan dari kegiatan ini adalah sebagai penutupan kegiatan mahasiswa KKN yang diselimuti dengan pengajian dalam rangka peningkatan Iman dan Taqwa.
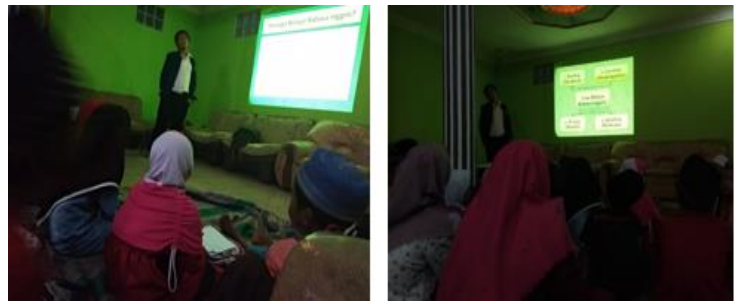

\section{Belajar bahasa inggris}

Kegiatan ini bertujuan agar anakanak gemar dan tidak sungkan untuk belajar dan berbicara dengan bahasa ingris.

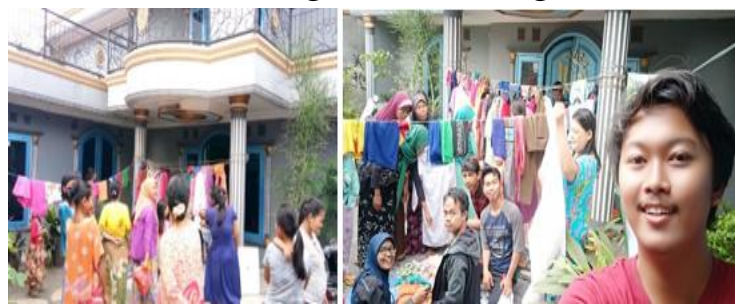

\section{Bazar Pakaian Bekas}

Tujuan dari kegiatan ini adalah untuk mempermudah warga dalam mendapatkan baju bekas dan murah tapi masih layak pakai. 


\section{KESIMPULAN}

Kegiatan KKN dengan sasaran Masyarakat Desa Bojong Rangkas secara umum berjalan dengan lancar sesuai apa yang direncanakan, meski target waktu yang direncanakan tidak dapat sepenuhnya dijalankan sesuai dengan hal tersebut, namun hal tersebut tidak merubah esensi pelaksanaan program tersebut. Adapun kesimpulan dari pelaksanaan program kerja KKN masyarakat yaitu :

1. Program KKN dapat terlaksana dengan baik dan lancar meski ada beberapa perubahan dan tambahan serta waktu pelaksanaan yang kurang sesuai dengan yang direncanakan.

2. Terbentuknya karakter building para mahasiswa dan mahasiswi yang mengikuti program KKN ini.

3. Meningkatkan kepedulian dan rasa empati mahasiswa kepada permasalahan masyarakat, sehingga terjadinya perubahan perilaku mahasiswa kepada masyarakat.

4. Program Kerja KKN dapat berjalan dengan baik berkat Ridho Allah, dengan perantara, dukungan dan kerja sama antar warga yang sangat membantu.

Selain itu, program KKN yang dilaksanakan oleh kelompok 10 juga memberikan dampak yang signifikan bagi masyarakat. Dampak bagi masyarakat diantaranya terbantukannya sekolahsekolah yang kekuarangan guru, meningkatnya kesadaran masyarakat terhadap pentingnya pendidikan agama, ilmu teknologi, dan bahasa asing seperti bahasa inggris, meningkatnya kesadaran masyarakat terhadap pentingnya menjaga kesehatan, dan terbantukannya masyarakat dengan adanya kerja bakti dan pembuatan gapura.

\section{SARAN}

Diharapkan masyarakat dapat melanjutkan program-program yang telah dilaksanakan oleh mahasiswa KKN Universitas Ibn Khaldun Bogor dan dapat meningkatkan kerjasama lintas sektor. Masyarakat dan pihak desa aktif bekerja sama dalam mengembangkan program kerja desa yang sudah ada dibuat oleh desa, dengan masukan di adakannya program untuk generasi muda - remaja yang diharapkan akan menjadi penentu kemajuan desa dikemudian hari. Adanya kontrol kerja desa dengan teknologi yang sudah berkembang, seperti rencana program desa, program yang sudah terlaksana, program yang selesai di bangun, jumlah kependudukan, kepengurusan desa agar program desa dapat terlaksana dan terkontrol lebih baik. 


\section{REFERENSI}

Eska Perdana Prasetya (2016), The Effect of Students' Perception on School Environment and Self-discipline towards Their Achievement in Learning English: A Survey at a Private Vocational School in Bogor

https://penduaismine.wordpress.com/2013/

04/30/penyuluhan-sebagai-suatuaktivitas sosial-pembangunan/

Subagyo, P. J. (2011). Metodologi

Penelitian Dalam Teori dan Praktek . Jakarta: Aneka Cipta.

Suyono, H., \& Haryanto, R. (2009). PEDOMAN PELAKSANAAN KKN $P O S$ PEMBERDAYAAN KELUARGA (POSDAYA). Depok: CITRA KHARISMA BUNDA. . (2018). Petunjuk Pelaksanaan KKN Tematik Terintegrasi 2018. Bogor : LPPM UIKA .(2017). Pedoman Pelaporan PPM UIKA 2017. Bogor. LPPM UIKA 